\title{
Research on the Financial System of Cambodia
}

\author{
Mingshan Jiang* \\ 1. International Cooperation and Exchange Office \\ Yunnan University of Finance and Economics \\ Kunming, Yunnan, China \\ 2. School of Knowledge Science \\ Japan Advanced Institute of Science and Technology \\ Nomi, Ishikawa, Japan \\ prajnapeace@qq.com
}

\author{
Ping Yang \\ Business School \\ Yunnan University of Finance and Economics \\ Kunming , China \\ 928915449@qq.com \\ Wen $\mathrm{Wu}$ \\ Kunming Local Taxation Bureau \\ Kunming, China \\ 540826358@qq.com
}

\begin{abstract}
As an important region covered by "The Belt and Road" in Southeast Asia, Cambodia has become a hot spot at present. The purpose of this paper is to elaborate the composition of Cambodia's financial system from three major aspects: The Overall Framework of Financial System, Financial Regulation System, and Financial Regulation System.
\end{abstract}

Keywords-Cambodia; Finance; the Belt and Road

\section{INTRODUCTION}

Cambodia is located in the southern part of the Indochina Peninsula. At present, it has a population of 17.57 million and a territory of 181 thousand square kilometers. The country's current export manufacturing industry is mainly driven by low-cost labor force as the national development strategy. Due to reasons that labor force cost has increased in other Asian countries such as China, more foreign investors start to consider making investments in Cambodia. According to the data shown in 2015, Cambodia's nominal GDP reached $\$ 18.5$ billion and the actual GDP growth rate was $6.9 \%$, which was higher than the global average growth rate of $3.1 \%$, and also higher than the average growth rate of $6.5 \%$ of the Asian emerging economies [1].

\section{THE OVERALL FRAMEWORK OF FINANCIAL SYSTEM}

\section{A. The Profile of Cambodia Banking Institutions}

\section{1) Central bank - national bank of Cambodia}

The banking industry of Cambodia is a single supervision system and the central bank whose headquarters located in Phnom Penh can be its regulator. Its main responsibilities include: formulating and releasing policies of bank currency and exchange rate, supervising banks and other financial institutions, as well as national currency [2]. According to the relevant data published by the central bank, the increasing rate of 2015 was comparatively slower than that of 2014, but with continuous growth of bankers and microfinance system, the major indicators such as the bank deposit amount and loan amount in 2015 turned out to be growing continuously. By the end of the year, the deposits of commercial banks and professional banks amounted to $\$ 11.5$ billion, leading to an increase of $16.7 \%$ compared with the $\$ 10$ billion in the same period in 2014[3]. At the same time, the loan balance reached $\$ 12$ billion, which increased by $25.8 \%$ over 2014[4]. The industrial average loan to deposit ratio already exceeded the nominal $100 \%$ standard.

\section{2) Commercial banks}

There are 36 commercial banks in Cambodia, including 27 domestic banks, 9 foreign banks and 37 other microfinance institutions. Compared with the developing economic scale, its coverage range can be limited, while many transactions are still taking place outside the financial departments.

Central Bank (referred to as National Bank of Cambodia: NBC) was first founded in 1996, with the head office and other 21 branches. According to provisions of the National Bank Law, the main functions of the central bank include implementation of financial policies, management of money supply, issuance of money, management of foreign exchange, approval and supervision of commercial banks establishment, etc. [5]. Regarding the regulation perfection of financial departments, the Insurance Law was enacted in 2000 and laws related to financial transactions and leasing industry will be formulated soon. The stock market has not been set up yet but the preparation work is going on through the technical cooperation with South Korea. This series of measures of perfecting the financial system is carried out mainly based on the financial department blueprint of the Asian Development Bank [6].

\section{B. Monetary Policy}

The Central Bank of Cambodia has been trying to adjust the monetary policy in a flexible way so as to cope with inflation. From 2007 to 2008, the global prices for food and fuel rose, which also hit Cambodia's economy. In response, NBC adopted a tight monetary policy. In the beginning of 2009 , in order to prevent the liquidity pressure in economy from upgrading to the systemic pressure, Cambodia shifted its monetary policy from moderately tight to moderately loose. In addition, the Central Bank of Cambodia has maintained a

*Corresponding author 
floating exchange rate system, which allowed the Riel exchange rate to be adjusted according to the external conditions.

In terms of interest rates, the fund source of the Cambodian bank system is mainly the US dollar from abroad. In the Cambodian market that pursues the free flow of funds, the Central Bank of Cambodia still has not established the benchmark interest rate policy, which makes it difficult to interfere with the interest rate trend of banks. Besides, both credit risks and operation costs of domestic commercial banks in Cambodia are quite high, which makes Cambodia become one of the countries in Southeast Asia with the highest costs of loan, and the gap of interest rates between deposit and loan is significant [1].

\section{Foreign Exchange Policy}

The currency of Cambodia is Riel. Since Cambodia implements the open market economy policy, the service fields including banks are completely open to foreign investors. Cambodia follows the eighth provision of IMF and does not impose any restrictions on payments and capital transfers under current items. In 1997, the Government of Cambodia approved and implemented the Foreign Exchange Law, which stipulates that the exchange rate is regulated by the market. There are no restrictions on foreign exchange trading, international settlement, capital flow, etc. The residents are allowed to hold foreign exchange freely. And any enterprises can open foreign exchange account as long as being registered in the Cambodia Business Competent Department. Moreover, the foreign exchange business handled through the authorized bank is not regulated but the authorized bank shall report to the central bank if the amount of a single transfer exceeds US \$10 thousand. However, the Central Bank of Cambodia can implement the temporary control measures no more than three months when there comes a foreign exchange crisis. In recent years, the exchange rate has been basically stable. In 2015, the exchange rate between Riel and the US dollar was basically the same as that in 2014, with an annual average exchange rate of 4050:1. In general, the risk of Kampuchea exchange is relatively low.

\section{FinanCial Regulation System}

\section{A. Bank Regulation System}

The banking in Cambodia uses a single regulatory system and the central bank is its regulatory institution, whose main functions include making and implementing monetary, credit and banking policies, maintaining the currency stability and promoting the economic growth, supervising the banking financial institutions, maintaining the banking stability, and implementing free foreign exchange policies. The Central Bank of Cambodia requires that the capital adequacy ratio of financial institutions should not be less than $15 \%$, and releases laws and regulations for the management of financial institutions, including the supervision of financial institutions, access and exit procedures of financial institutions, payment and liquidation management, anti-money laundering, etc.

\section{B. Insurance Regulation System}

\section{1) Insurance regulation}

Since 2001, the government has begun to implement the Insurance Law, and also released various kinds of ministerial orders, such as the Qualification Order of Insurance Company and Foreign Capital Insurance Company Establishment, the Qualification Order of Insurance Company, Agent and Brokerage Firm, etc. In 2007, the important provisions concerning business license, solvency and corporate governance were also issued [7]. On June 27, 2014, the Cambodia Congress audited and approved the draft of the New Insurance Law, which aimed to ensure the management of Cambodian insurance industry and meet standards of the ASEAN, the World Trade Organization and the International Insurance Association. The draft consists of 14 chapters and 114 articles in total, which has covered a wide range of insurance business activities, including general insurance, life insurance and micro-insurance, etc. [8].

\section{2) Market access}

The Insurance license can be divided into four categories: financial insurance companies, life insurance (including health insurance) companies, comprehensive insurance companies and small insurance companies (low requirements for solvency, only allow for small insurance business). The insurance company must be established as a limited liability company and its business license and certificate are issued by the Ministry of Finance and Economics, which should be updated 5 years after first issuance, and will continue to be updated every three years thereafter [7].

\section{3) Solvency regulation}

The minimum solvency requirement is to take the higher amount between the $30 \%$ of last year's premium and 6 billion Riel. As stipulated, at least 2.8 billion Riel of the repayments are required to be deposited in NBC or used to purchase government bonds. And the minimum solvency for a small insurance company is 400 million Riel, which must be deposited in banks approved by the government. At present, the Ministry of Finance and Economics does not have any regulatory provisions for withdrawing reserve funds. The government implement the solvency supervision to insurance companies and reinsurance companies, and for those enterprises not meeting the requirements, they will be ordered to stop doing business and rectify, or moreover their business licenses can be revoked. On the whole, the solvency regulation mode in Kampuchea is approximately similar to that in the early stage of EU Solvency I [9].

\section{4) Rate and provision regulation}

As stipulated in the Insurance Law, the insurance rate shall be used after approved by the Ministry of Finance and Economics, and the detailed reference rate is determined by GIAC which was established in 2005. The property insurance company must adopt the reference rate otherwise it will get the corresponding punishment. In terms of life insurance, the reference rate of products is mainly based on the rates charged in the countries of foreign shareholders of each insurance company. The Ministry of Finance of Economics requires the insurance companies to report afterwards about used provisions, insurance paper documents and other sales 
materials. If any error is detected, the insurance company will be ordered to make changes. Currently, the Ministry of Finance and Economics is planning to launch a unified standard provision for the whole industry in the near future [7].

\section{5) Other regulatory measures}

In 2008, the government promulgated the Ministerial Order of Insurance Accounting Standard and required the insurance companies to fully implement the Cambodia Financial Report Standard (CFRS) after the accounting year of 2010, which has taken the International Financial Report Standard (IFRS) as the blueprint [7].

\section{Security Regulation System}

On October 19, 2007, Cambodian government promulgated the Law of Non-government Bonds Issuance and Trading, which laid a legal foundation for security market development. In order to accelerate the Cambodian security market process, the Cambodia Ministry of Finance and Economics selected the Korea Stock Exchange (KSE) as the business partner to solve the problems of talents, technology and capital in the process of developing its security market. On January 21, 2008, the Cambodia and Korea have signed a memorandum of understanding about the "securities market establishment in Cambodia Kingdom".

Due to the global financial crisis in 2008, the plan to set up Cambodia security market in September 2009 was disrupted. However, sometimes bad things can be changed into good things. During 2008 and 2009 when the financial crisis broke out and its effect extended, the Cambodia Securities Exchange Committee has completed the promulgation of 9 laws and regulations, including the Regulation Method of Stock Public Issuance, and established a relatively complete legal system. However, since in some listed companies, the large number of shares are still held by state-owned enterprises and without complete audit system to standardize the enterprises' disclosure of financial situation and performance information, the behavior of valuation manipulation is hard to avoid.

\section{RISK OF FINANCIAL SYSTEM}

\section{A. The Financial System in Cambodia is Incomplete and Business Scope can be Narrow}

Currently, its convenience, effectiveness and stability of financing are quite poor and cannot satisfy the needs for ASEAN Free Trade Area as well as the economic globalization, which bring some obstacles and risks to the foreign investors. The banking system of Cambodia consists of the central banks, professional banks and commercial banks, while the proportion of foreign banks, foreign-related financial institutions and non-financial institutions are relatively small. Besides, the financial system is also imperfect and major financial businesses such as deposit and loan in various countries are monopolized by a few large commercial banks. For example, the greater 5 commercial banks in Cambodia including KA WAH Bank and Foreign Trade Bank have taken up $70 \%$ of the total national bank assets and $80 \%$ of the savings deposit, and meanwhile offered $70 \%$ of the loans [1].
The financial stability is low and the World Bank has reduced its credit scale, but domestic credit growth has been too fast

Under the premise of Cambodia's increasing demand for credit loans, the growth rate of the Word Bank's credit amount is declining, which cannot meet the needs of Cambodia's effective use of bank credit to improve the domestic environment. To a certain extent, this has hindered the development of Cambodia. On the other hand, Cambodia's domestic economy is quite active, especially for greatly increased price of real estate, which enlarges the growth of credit rapidly. In 2015, the average growth rate of domestic credit reached $23.9 \%$. As the credit growth is too fast and mostly concentrated in the real estate industry, the financial stability of Cambodia is under greater pressure. Even if the Central Bank of Cambodia raised the reserve funds ratio of commercial banks, or took macro prudential measures to set the upper limit for real estate loans, the monetary policy effect of Cambodia was very limited because of the highly dollarization of Cambodian economy [1].

\section{B. Lack an Effective Loan Management System}

In Cambodia, the World Bank's credit assistance is mainly used in 5 departments, including agriculture, government administration, environment, health and education. Under the premise of developing agriculture as the first industry, the government actively makes investments in improving the medical and health conditions, and trying to solve some serious problems in Cambodia such as the increasing patient number of infectious diseases, like AIDS. However, since the total amount of credit is small, the funds available for investment are insufficient and proportion invested in health care is still inadequate, the current level of medical service has still not been improved and the government's ability to deal with infectious diseases can be still weak. Considered as the country of the highest rate of AIDS infection in Asia, Cambodian government is still unable to provide effective drug treatments to the domestic AIDS patients.

\section{Lack Perfect Financial Platforms and Channels}

Cambodia has been trying to reform its original market mechanism, introduce the market decision mechanism into market competition, and try to determine the competitive relationship between enterprises through price and other market factors. Since all monopoly companies in Cambodia are state-owned enterprises, so the reform of market mechanism is still embodied in encouraging the state-owned enterprises to participate in market competition and guiding the integration of private capital and state capital. However, the reform of market mechanism is not only to attract private enterprises and state-owned enterprises to participate in the market competition and diversify the market subject, but more importantly aims to establish a perfect financial platform and provide more powerful material guarantee for the financing and competition of enterprises. However, Cambodia mainly makes use of the aid funds from World Bank in developing the agriculture and environment entities, as well as improving the living conditions of its people, while ignoring the financing and development demand of domestic enterprises. With less 
investments in improving the market competition environment the financial market set up by Cambodia still has a large gap in scale, efficiency and other aspects when compared with that in other countries. Thus, it can be seen that Kampuchea still has much room for development in establishing a sound financial platforms and financing channels.

\section{CONCLUSION}

The current development strategy adopted by Cambodia is the "Asian Factory" economic developing mode, which uses low price labor force to promote export manufacturing industry [10]. But Cambodian government has concentrated on the industrial transformation and upgrading, and released the "Cambodian Industry Development Policies between 2015-2025" in March of 2015, which put forward the "Four Angle New Increase Strategy" and plans for new development direction of industry so as to dock with the "The Belt and Road" construction, promote the cooperation with China in infrastructure construction, industrial and commercial finance and other fields, and achieve mutual benefit and common development.

In general, the economic entity volume of Cambodia is relatively small and its financial system has long-standing problems including imperfect management system, low stability, lack of effective loan management mechanism and financing platform, etc. The financial market in Cambodia is still in the initial stage of development. The financial structure of banks and small micro finance as the major part is in harmony with the level of economic development at this stage. At the same time, the financial development of Cambodia has benefited from the role of foreign investment to a certain degree, especially when foreign financial institutions enter into the country, its international financing channels has been expanded and the stability of its financial system has been effectively maintained [11]. Due to the sharp increase in mobile phone usage in Cambodia, mobile payment has become the ice-breaking point for the Inclusive Finance development. The government of Cambodia has continued to promote the reform of laws and regulations, the construction of capacity, the improvement of standards, financial transparency and the establishment of major financial infrastructures in order to strengthen Cambodian financial system [12]. Since Cambodia's foreign exchange is not controlled and the degree of freedom is relatively high, there is great room for cooperative development in economic and trade as well as finance aspect. For this reason, it is necessary for Cambodia to make some innovations for its remediable shortcomings, such as improving financial inclusiveness, innovating credit scores and widening financing channels for small and medium-sized enterprises.

\section{ACKNOWLEDGMENT}

I want to take this chance to appreciate my colleague Ms. Ping Yang, who gives me useful literature knowledge and information in this paper, and my friends for their considerate support to help me complete the article.

\section{REFERENCES}

[1] "The Risk Analysis Report of Cambodian Economic \& Commercial Environment", International Financing, Vol.1, 2017, pp.67-71.

[2] G. Xu, M. Su, X.H. Zhou, "Chapter 2: Central Bank Law”, Financial Law Introduction and Case, China Financial Publishing House, 2004.

[3] Anbound, "Singapore Promotes the Financial Technology Development", Financial Times, vol.7, 2016, pp.44-45.

[4] Cambodian Banking Industry Comes to Rapid Growth Period, http://www.cqvip.com/QK/84342A/201619/669541244.html

[5] Cambodia in the "Belt and Road Initiative", http://www.docin.com/p1588184724.html?docfrom=rrela

[6] H. Tanaka, X.M. Liu, "Cambodia's Economic Development and Current Situation of Financial Departments-Southeast Asian Studies", vol.2, 2008, pp.50-57.

[7] Southeast Asian Insurance Market Research No.10-Cambodia Market Vigorously Develops Micro Insurance, http://www.docin.com/p1940121954.html

[8] Cambodia Congress Deliberates and Approves the New Insurance Law Draft, http://www.qzbsg.gov.cn/zt/gzdm/Details/5be76f06-d4ec-4414bc1b-f422e7651bad

[9] Cambodia Market Vigorously Develops Micro Insurance, http://xw.sinoins.com/201601/21/content_182626.htm?from=groupmessage \&isappinstalled=0

[10] "Russia Cooperate with ASEAN: "Temporary" Opportunity or Partner in Future?", Financial Times, vol.8, 2016, pp.44-46.

[11] Cambodia Promotes the Inclusive Growth in the Financial Industry, http://intl.ce.cn/sjjj/qy/201707/06/t20170706_24052046.shtml

[12] Special topic:Cambodia Financial Industry, http://www.caexpo.com/special/economy/Cambodia_financial/ 